${ }^{49}$ Rome Statute of the International Criminal Court, UN Doc A/CONF.183/9, 17 July 1998.

${ }^{50}$ Jfr. Träskman, Inrättandet av en internationell domstol för brottmål. NTfK 1994 s. 143-160.

${ }^{51}$ Se t.ex. krönikor av Matti Joutsen, NTfK 1999 s. 220-226 och 320-325.

${ }^{52}$ Se särsk. Mireille Delmas-Marty, The European Union and Penal Law. European Law Journal, vol. 4 , 1998, s. 87-115.

${ }^{53} \mathrm{Om}$ den optimistiska synen se t.ex. Payam Akhavan, Justice in the Hague, Peace for the former Yugoslavia? Human Rights Quarterly, vol. 20, 1998, s. 737-816 (751); om skepticism se Träskman, Etablering av en internationell brottmålsdomstol. NTfK 1993 s. 169-208 (204).

${ }^{54}$ Se André Klip - Göran Sluiter (eds.), Annotated Leading Cases of International Criminal Tribunals, vol. I, Intersentia et al., 1999, s. 9.

${ }^{55}$ Se Convention on the Protection of the Environment through Criminal Law (4.XI.1998, European Treaty Series 172) och Criminal Law Convention on Corruption (27.I.1999, European Treaty Series 173).

${ }^{56}$ Delmas-Marty, Politique Criminelle d'Europe. I verket Nils Jareborg (ed.), Towards Universal Law. Uppsala 1995, s. 55-90. Se även samma (ed.), What Kind of Criminal Policy for Europe? The Hague 1996, passim; samma, Les Défis d'un Droit Pénal Européen. I verket Veijo Heiskanen - Kati Kulovesi (eds.), Function and Future of European Law. Helsinki 1999, s. 185-206.

${ }^{57}$ Delmas-Marty, i verket What Kind of Criminal Policy for Europe? s. 311

${ }^{58}$ Se närmare Delmas-Marty, European Law Journal 1998 s. 87-115; Peter-Alexis Albrecht - Stefan Braum, Deficiencies in the Development of European Criminal Law, European Law Journal, vol. 5, 1999, s. 293-310.

${ }^{59}$ Se Consolidated version of the Treaty on European Union, artiklarna 29-32; Action Plan, adopted by the Justice and Home Affairs Council of 3 December 1998 (1999/C 19/1).

${ }^{60}$ Sieber, A Model European Penal Code, Council of Europe, Parliamentary Assembly, Committee on Legal Affairs and Human Rights, 5 February 1997, AS/Jur (1996) 76. Memorandum har publicerats också på svenska, se NTfK 1997 s. 237-261.

${ }^{61}$ Se Delmas-Marty, Corpus Juris. Economica 1997.

${ }^{62}$ Se M. Delmas-Marty - J.A.E. Vervaele (eds.), The Implementation of the Corpus Juris in the Member States. Vol. I. Intersentia 2000.

${ }^{63}$ Greve, i verket Towards Universal Law s. 91-116 (112); samma, i verket Legal Issues at the Dawn of the New Millennium s. 49-56. Samtidigt konstaterar han, att "we have embarked on a 'single train' heading towards unification within criminal law with shorter or longer stops at intermediate stations, along the way to harmonization" (i sistnämnda verket s. 50).

${ }^{64}$ Om denna diskussion se särsk. Träskman, "Corpus juris" - Ett frestande eller ett främmande förslag till en enhetlig europeisk rättssfär? NTfK 1997 s. 262-277; samma, A Good Criminal Policy is More Than Just New Law, i verket Function and Future of European Law s. 207-219; Kimmo Nuotio, Should Criminal Law Be Our Common Interest? Ibid. s. 221-232.

${ }^{65}$ Med anledning av det sagda se också t.ex. Delmas-Marty (ed.), The Criminal Process and Human Rights. Toward a European Consciousness. The Hague 1995, passim; Jan Taylor, Crime, MarketLiberalism and the European Idea. I verket Vincenzo Ruggiero et. al., The New European Criminology. London 1998, s. 19-36.

${ }^{66}$ I det sistnämnda hänseendet se Pöysti, i verket Nordisk identitet s. 152-153.

${ }^{67}$ Garland, Editorial. Punishment and society today. Punishment \& Society, vol. 1, 1999, s. 5-10 (8).

Adress: Juridiska fakulteten

PB 4 (Universitetsgatan 3)

FIN-00014 Helsingfors universitet

E-post: raimo.lahti@helsinki.fi

Artikeln har delvis översatts och delvis språkligt bearbetats av jur.lic. Markus Löfman. 


\section{OM DEN KRIMINALPOLITISKE UTVIKLINGEN DE SISTE TIÅR}

\section{Av PROFESSOR HENRY JoHn MÆLAND}

This article, examines trends in Norwegian crime politics during the last decades. Analysis begins with a 1978 Norwegian governmental report on crime politics which was rather radical. This report promoted a more liberal approach to the traditional crimes of theft and violence, and a more repressive approach to white collar and environmental crimes. Ultimately, however, the suggestion to handle traditional crimes more leniently was not approved. On the contrary, the enforcement and punishment of offences involving theft and violence became mostly harder, especially during the last decade. Nonetheless, the Norwegian Parliament did approve a number of new statutes designed to fight white collar and organised crime. These statutes provide both new categories of criminal offences and a broader range of investigatory techniques for law enforcement. It should be stressed that many of these changes were influenced by recommendations from the Council of Europe.*

\section{Innledning}

I mitt innlegg vil jeg redegjøre for noen utviklingstendenser først og fremst i Norge, men da slik at stedvis blir også forhold i de øvrige nordiske land trukket inn.

Innledningsvis nevner jeg at bruk av straff mot narkotika har satt et betydelig preg på kriminalpolitikken de siste tiår. Men da narkotikapolitikken er satt opp som særskilt tema senere på møtet, vil jeg berøre dette bare i begrenset utstrekning. Jeg vil konsentrere meg om vinnings- og voldsovertredelser.

Det kan være hensiktsmessig først å gi noen meget grove tall på kriminalitetsutviklingen i Norge siste halvdel av forrige århundre.

Om lag $2 / 3$ av de etterforskede forbrytelser er vinningsovertredelser. Antall etterforskede tyverier har økt fra ca 30000 tidlig på 1960-tallet til ca $180000 \mathrm{i}$ siste halvdel av 1990-årene. Grove tyverier har i den samme periode blitt ti-doblet.

En dramatisk økning har også funnet sted for voldsovertredelser. Utviklingen av etterforskede forbrytelser fra 1957 til 1986 viser at tallet på voldtekt er tredoblet, legemsbeskadigelser og drap femdoblet og ran nidoblet. Denne utviklingen fortsatte ut i 1990-årene. I 1990 var det registrert 9000 anmeldte legemskrenkelser, mens det i 1995 var registrert 12000 (Kriminalstatistikk 1990 og 1995 utgitt av Statistisk sentralbyrå).

* Title in English: The Tendencies of the Norwegian Crime Politics in the Last Decades. Original in Norwegian. 
I de aller siste årene ser man en utflating og i det siste året også nedgang (St.prp.nr. 1 (1999-2000)).

I Danmark har man hatt en tilsvarende utvikling og da også slik at man der fikk en utflating og i 1998 sogar nedgang i anmeldte forbrytelser.

\section{Nyklassisisme og Kriminalmeldingen av 1978}

\subsection{Finland og Sverige lovfester nye straffutmålingsprinsipper}

Skal linjene i kriminalpolitikken trekkes fra 1970-årene kommer vi ikke forbi å kommentere debatten og omskiftet $\mathrm{i}$ idégrunnlaget for straff.

Som kjent svinget begrunnelsen for straff som middel til kriminalitetskontroll meget i forrige århundre. Fram til 1960-årene sto behandlingsideologien og hensynet til resosialisering sterkt. Men da snudde pendelen formelig 180 grader.

I de nordiske land fikk man en omfattende debatt med krav om lovrevisjoner og endring av strafferammer og straffutmålingsprinsipper basert på handlingenes straffverdighet, et idegrunnlag som ofte ses betegnet som den nordiske nyklassisisme.

Et slikt idegrunnlag førte til lovendringer for straffutmålingsprinsipper, først $\mathrm{i}$ Finland og senere i Sverige.

I 1972 ble det i Finland nedsatt en komite for å forberede en totalreform av den finske straffelov. I 1976 la komiteen fram en betenkning hvor det ble uttalt at grunnlaget for straffen må søkes i almenprevensjonen. Straffesatsene i loven - og den straff som utmåles i den enkelte sak - kunne derimot ikke fastsettes ut fra almenpreventive hensyn. Straffen måtte i stedet baseres på normative betraktninger om hvilken straff lovbruddet fortjente. Straffen skulle utmåles etter handlingens straffverdighet.

På grunnlag av denne innstilling ble straffutmålingsprinsippene endret i den finske straffeloven kap. $6 \S \S 1-3$.

I Sverige erfarte man en tilsvarende utvikling. En arbeidsgruppe nedsatt av "Brottsforebyggande rådet" som hadde fått i oppdrag å vurdere straffesystemet avga i 1977 sin innstilling: "Nytt straffsystem" som anbefalte at det sentrale element ved straffutmålingen skulle være handlingens straffverdighet. Foruten rettferdshensyn ble dette begrunnet $\mathrm{i}$ hensynet til almenprevensjonens moraldannende funksjon, jfr. Arbetsgruppen rörande kriminalpolitik 1977 s. 200.

Straffutmålingsprinsipper basert på et krav om forholdsmessighet mellom forbrytelse og straff, ble igjen lagt til grunn i en innstilling avgitt av Fängelsesstraffkommitten oppnevnt i 1979 for å utrede bruken av fengsel. Innstillingen ble avgitt i 1986 (SOU 1986:13-15 Påföljd för brott”). Og i 1988 ble et slikt straffutmålingsprinsipp lovfestet i den svenske Brottsbalken kap. 29.

Den svenske lovrevisjonen åpnet imidlertid for modifikasjoner. For eksempel kunne det tas hensyn til personlige forhold vedrørende gjerningspersonen i formildende retning, dersom en straff utmålt etter straffeverdien ville bli for streng. 
Og i skjerpende retning kunne det fortsatt legges vekt på forstraffer og lovbruddets art. De praktiske forskjeller blir derved ikke så store i forhold til tidligere.

Senere har Straffsystemkomittén i fremlagt en innstilling (SOU 1995:91) som förer videre "proporsjonalisme"-tanken.

Både i Finland og i Sverige var det anført at den straffbare handlingens straffverdighet også skulle komme til uttrykk ved fastsettelsen av strafferammene i loven. Straffebudene burde differensieres sterkt i ulike grovhetsgrader ved straffeskalaer for de enkelte forbrytelser hvilket ville innebære en reduksjon av dommerfriheten under den konkrete utmålingen. Til forskjell fra konkret straffvärde talte man her om abstrakt straffvärde.

\subsection{Den norske Kriminalmeldingen av 1978}

Verken i Danmark eller i Norge fikk de nyklassisistiske tanker det samme gjennomslag. På slutten av 1970-tallet hadde vi i Norge likevel en heftig debatt knyttet til at Regjeringen - i 1978 - la fram en radikal kriminalmelding som i stor grad bygger på nyklassisistisk retorikk, jfr. St.meld.nr. 104, 1977-78 Om kriminalpolitikken.

Men tanker om økt vekt på forholdsmessighet mellom forbrytelse og straff førte ikke til endringer i norsk kriminalpolitikk. Hva angår straffutmålingen, var man ikke uenig i at straff som utgangspunkt skal avpasses etter forbrytelsens grovhet. Dette har vel til alle tider vært et sentralt utgangspunkt. Men det var liten oppslutning om å endre straffutmålingstradisjonen som i Norge kan ha sterke innslag av pragmatisme og hvor domstolene også vektlegger individualpreventive og almenpreventive hensyn ved den konkrete straffutmålingen.

Først og fremst fremsto imidlertid den norske Kriminalmeldingen som et program om et omskifte i kriminalpolitikken til større liberalitet ved såkalt tradisjonell kriminalitet, og skjerpet straff overfor såkalt moderne kriminalitet.

Tradisjonell kriminalitet blir i meldingen definert som handlinger som var belagt med straff også før Norge ble et moderne industrisamfunn, som for eksempel voldsovertredelser, tyveri, ildspåsettelse og sedelighetsforbrytelse. Moderne kriminalitet var straffbare handlinger som hang sammen med utviklingen til et moderne samfunn. Som eksempler blir nevnt skatte-og avgiftsunndragelser, prisovertredelser, overtredelser av trafikklovgivning og arbeidsmiljøbestemmelser.

I nyklassisistisk ånd blir det i meldingen uttalt at strafframmene i de enkelte straffebud burde gi uttrykk for handlingenes straffverdighet, og det blir tatt til orde for en omprioritering av strafferammer og bruk av straff ved de ulike typer delikter. Tradisjonell kriminalitet burde nedkriminaliseres og moderne kriminalitet oppkriminaliseres.

Det uttales at mens man hadde kunnskaper om at almenprevensjonen kunne virke kriminalitetsforebyggende overfor den moderne kriminalitet, visste man lite om virkningene av almenprevensjonen ved tradisjonell kriminalitet, men 
rettferdshensyn var en sosial realitet, og straff burde fastsettes basert på hensyn til rettferd og humanitet.

Tradisjonell kriminalitet ble begått av ressurssvake unge menn med store personlige problemer. Straffverdigheten ved vinningskriminalitet var blitt redusert med tiden, idet vi som borgere i dag rammes mindre hardt da vi har blitt rikere og allerede er inndekket gjennom forsikringsordninger.

Ved tradisjonell kriminalitet skulle det anvendes mindre varetektsfengsel, gis færre ubetingede dommer, gjentagelse skulle tillegges mindre vekt ved straffutmålingen, og løslatelse på prøve skulle som regel skje etter halv tid. I tillegg skulle selve frihetsberøvelsen gjøres lettere og adgangen til permisjon utvides.

I Norge var det mange som var kritiske til deler av innholdet i Kriminalmeldingen. Det ble fremholdt at meldingen ga dels uriktige og dels fortegnede beskrivelser av strafferettspleien. Blant annet gjaldt dette behandlingen av vinningsovertrederne.

Det kom i det hele sterke reaksjoner mot å svekke vernet for privat eiendom. Det ble fra flere hold fremholdt at en redusert bruk av straff overfor vinningsovertrederne - etter Kriminalmeldingens program - ville føre til en betydelig $ø$ kning av kriminaliteten (Johs. Andenæs, Georg Fr. Rieber-Mohn, L.J. Dorenfeldt og Olav T. Laake, Kommentarer til KRIMINALMELDINGEN, Oslo 1979, s. $36,46,66-67)$.

\section{Opptrapping av kampen mot økonomisk kriminalitet}

Mens kriminalmeldingens liberale program overfor vinningsovertredere ble forkastet, ble det i Norge arbeidet videre med flere andre tilrådinger i meldingen:

For det første ble den kriminelle lavalder hevet fra 14 til 15 år, og Norge kom da på linje med de øvrige nordiske land.

For det andre ble det i Norge opprettet et kriminalitetsforebyggende råd. Et tilsvarende råd var for øvrig allerede opprettet i Danmark og Sverige.

For det tredje er offerets stilling styrket. Ved den nye straffeprosessloven av 1981 er hovedregelen at påtalemyndigheten har plikt til å fremme fornærmedes erstatningskrav i straffesaken, og det er innført en ordning med bistandsadvokat i sedelighetssaker.

For det fjerde ble det i 1980 nedsatt en straffelovkommisjon til å forestå en full revisjon av straffeloven.

Den norske straffelovkommisjonen har til nå fremlagt enkelte delutredninger av generell karakter og en utredning om seksuallovbrudd. Utkastet til bestemmelser i straffelovens alminnelige del som ble fremlagt høsten 1991 (NOU 1992:23) viderefører stort sett tradisjonen i någjeldende straffelov.

Av kriminalmeldingens forslag er det særlig opptrappingen av kampen mot ulike former for økonomisk kriminalitet som til nå har hatt størst praktisk betydning.

Etter betydelig innflytelse fra tilrådinger i Europarådet har man i Norge - og i 
de øvrige nordiske land - hatt en utvikling på 1980- og 1990-tallet i retning av straffskjerpelser mot flere av de former for kriminalitet som Kriminalmeldingen betegner "moderne" kriminalitet. Vi har fått nykriminaliseringer mot krenkelser av miljø og data, en utvidelse av heleribestemmelsen som blant annet også omfatter hvitvasking, og generelle regler om foretaksstraff m.m. I tillegg har det i Norge blitt iverksatt mange tiltak for å lette oppdagelse, sikre bevis og lette iretteføring av straffesaker mot konkurs- og skatte- og avgiftskriminalitet. Et vesentlig stikkord er etableringen av Økokrim.

I Danmark vedtok man i 1997 regler med utvidet adgang til inndragning (formueskonfiskasjon), også av formue på ektefelles hånd og med omvendt bevisbyrde. Endringene synes her å ha bygget på forslagene til det norske Inndragningsutvalget - NOU 1996:21. Tilsvarende vidtrekkende regler ble vedtatt i Norge i 1999. Samme år la et utvalg i Sverige fram forslag om nye regler om utvidet adgang til inndragning som rett nok ikke går fullt så langt som de dansk-norske regler (SOU 1999:147).

\section{Om behandlingen av tradisjonell vinningskriminalitet}

Som nevnt førte Den norske Kriminalmeldingen ikke til noen liberalisering overfor vinningsovertrederne. Utover 1980-tallet var kriminalpolitikken på dette området relativt stabil i Norge. Men et sentralt tema i Norge og i Norden var likevel å få redusert bruken av fengselsstraffen og å få ned soningskøene ved fengslene.

I Danmark vedtok Folketinget i 1982 et forslag om å endre strafferammene for vinningsovertredelser i mildere retning. For eksempel ble maksimumsstraff for grovt tyveri nedsatt fra 6 til 4 års fengsel. Lovendringen siktet på "en betydelig sænkning af strafudmålingsniveauet for berigelsesforbrydelser...med gjennemgående en tredjedel".

Hovedargumentet var ønsket om en "begrænsning i anvendelsen af frihedsstraf". Men en vesentlig drivkraft var også soningskøer, jfr. Folketingstidende 1981-82. 2.samling. tillæg A sp. $4521 \mathrm{flg}$.

Undersøkelser av domstolspraksis viser at 1982-reformen førte til en nedsettelse av frihetsstraffene med ca 1/4, jfr. Britta Kyvsgaard i Juristen nr. 41995 s. 166 flg.

I Sverige fikk man i 1983 en såkalt "halvtidsreform" for soningsfanger. Dette var en reform som også fikk betydning for andre fanger enn vinningsovertrederne.

Fanger med dommer på mer enn to måneder og under 2 år skulle obligatorisk frigis etter soning av halv tid og ikke $2 / 3$ som var den alminnelige regel.

En ordning som det ble reist stort håp til med sikte på å få ned bruken av fengselsstraff, var innføring av samfunnstjeneste.

På slutten av 1980-tallet ble det i Norge satt $\mathrm{i}$ gang en prøveordning med samfunnstjeneste som alternativ til ubetinget fengsel med vinningsovertredelse som 
kjerneområdet. Noen år senere - i 1991 - ble samfunnstjeneste vedtatt i Norge som en hovedstraff, og det ble oppfordret til økt bruk av samfunnstjeneste som alternativ til ubetinget fengsel. Også i de andre nordiske land ble innført samfunnstjeneste.

Signalene på 1990-tallet har imidlertid gått i retning av en mer repressiv strafferett. I 1991 la Regjeringen fram en ny kriminalmelding (St.meld. nr. 23 199192) som vektlegger effektivitet og kamp mot såkalt "hverdagskriminalitet".

Senere er det vist til undersøkelser - fra USA og også fra Sverige - som har påvist at en relativt betydelig andel av kriminaliteten kan tilbakeføres til en liten gruppe svært aktive gjengangere og det er tatt til orde for økt inkapasitering av disse personer.

Videre har mange politikere nærmest entydig fremmet krav om strengere straffer. Debatten i media har i stor grad vært fokusert på slike signaler. Forsvarergrupper og forskere som måtte ha motforestillinger, er i mindre grad hørt. Slik sett har det til dels funnet sted en avprofesjonalisering av kriminaldebatten.

Lignende trekk ses i Sverige og Danmark. For eksempel ble det satt en slutt for "halvtidsreformen" i Sverige i 1993, da det der hadde kommet strømninger om en strengere kriminalpolitikk.

Samlet sett er det fengsel som har tatt over. Mens bruk av samfunnstjeneste økte noe i første halvdel av 1990-årene i Norge, har tallet på samfunnstjenestedommer de siste årene faktisk blitt halvert.

På den annen side har kontrollen av residivistene blitt trappet betydelig opp.

Ved flere store politidistrikter settes det opp en såkalt verstingsliste. Overfor denne gruppen drives det aktiv spaning og straks vedkommende begår en ny overtredelse, begjæres varetektsfengsling og vedkommende tas ut av "sirkulasjon", og holdes fengslet fram til pådømmelse og etterfølgende soning.

Varetektsfengsling blir dermed et vesentlig virkemiddel, og forslag om senking av terskelen for varetekt overfor gjengangere er for øvrig nå under utredning.

For å gjøre systemet mer effektivt er videre strpl. § 13 nylig endret, og da slik at en straffbar handling nå kan pådømmes straks den er ferdig etterforsket, og da uten å måtte avvente etterforskningen av andre straffbare handlinger fra samme person med sikte på forening.

Parallelt med den effektive håndhevingen overfor de mest aktive gjengangerne, har påtalemyndigheten i Norge krevd en hevning av straffenivået.

Ved dom gjengitt i Rt. 1997 s. 1976 ga Høyesterett støtte til dette kravet, og straffnivået har $i$ de senere år blitt hevet med ca $25 \%$ ved saker med større omfang.

Håndhevingen overfor gjengangerne ved vinningskriminalitet de siste år har vært effektiv. Det kan nå - for første gang på mange år - vises til en markant nedgang av kriminaliteten, og det antas at iallfall noe av denne nedgangen skyldes dette arbeidet. 
I Riksadvokatens prioriteringsrundskriv (Rundskriv nr. 1/2000) vises det til at det nå registreres en nedgang av vinningskriminaliteten, og det anføres på s. 11 at arbeidet "med å heve straffene overfor denne gruppen skal videreføres" og på $\mathrm{s} .8 \mathrm{i}$ samme rundskriv uttales:

"Overfor aktive tilbakefallskriminelle kan en ikke regne med at straffen i tilstrekkelig grad virker avskrekkende. Her må samfunnets behov for beskyttelse ivaretas ved at lovbryterne i en periode forhindres fra å begå ny kriminalitet. Straffens inkapasiterende virkning bør i disse tilfeller i særlig grad påvirke hva som er en adekvat reaksjon."

For tiden har inkapasiteringstanken vind i seilene. Det nevnes stadig av politikerne, og tankene har kommet til utslag i aktiv politikk, senest ved et rundskriv av 1999 fra Justisdepartementet til fengselsdirektørene om at det ikke lenger skal være like lett med prøveløslatelse etter $2 / 3$ soning for gjengangerne.

\section{Oppkriminalisering av voldsovertredelser}

Den norske Kriminalmeldingen av 1978 rubriserte voldskriminaliteten som tradisjonell kriminalitet og i meldingen blir også behovet for strenge straffer mot voldskriminaliteten nedtonet.

Men også på dette området har utviklingen i Norge gått i en annen retning. Fra lovgivers side skjer det en skjerpelse ved en lovendring av $1989 \mathrm{i}$ bestemmelsene om legemskrenkelser, særlig ved tilføyelser i strl. § 232 om skjerpet straff ved vold begått av flere i fellesskap og ved vold som har karakter av mishandling. Utover på 1990-tallet har vi deretter fått en markant hevning av straffnivået både av legemskrenkelser og voldtekt i rettspraksis (Se Anders Bratholm/Magnus Matningsdal, Straffeloven med kommentarer, Anden Del, Forbrydelser, Oslo 1995 s. 584-585) og da slik at Riksadvokaten uttaler at han er tilfreds med det straffenivå som er lagt ved de nyere dommer.

Likevel ser man at det blant mange politikere fortsatt er misnøye med straffenivået. I 1998 (se Stortingsforhandlinger: Dokument nr.8:60 (1997-98)) fremmet enkelte stortingsrepresentanter det uvanlige forslag om å treffe vedtak $\mathrm{i}$ Stortinget hvor Stortinget uttaler at domstolenes straffeutmålingspraksis i draps- og voldssaker og sedelighetssaker mot mindreårige er for lave og at det "henstilles til Høyesterett og landets øvrige domstoler å vurdere om ikke det generelle straffutmålingsnivå for slike forbrytelser bør skjerpes vesentlig innenfor de någjeldende [straffe-]rammer". Selv om det rådende syn var at straffenivået burde heves, var det i Stortinget ikke flertall for å fatte et plenumsvedtak med slik direkte politisk styring rettet mot domstolenes straffeutmålingspraksis.

Også i Danmark skjer en opptrapping av straff mot voldskriminalitet. I 1997 ble det i Folketinget votert over et lovforslag om at det ved særlig grov vold skulle tillegges 1 års fengsel i de tilfeller hvor det tidligere var utmålt fengsel $\mathrm{i}$ mer enn 1 år. Forslaget ble vedtatt som en del av en samlet "voldspakke" som også inneholdt flere andre tiltak mot voldskriminaliteten. Det rigide forslag om ett års tilleggsstraff ble imidlertid myket opp da forslaget ble drøftet i Folketinget slik at resultatet ble en alminnelig hevning av straffenivået. 


\section{En kommentar til fangetallet}

På 1970- og 1980-tallet var spørsmålet om reduksjon av fengselsstraff et sentralt tema $i$ alle de nordiske land.

Det er likevel bare Finland som i betydelig grad har maktet å redusere bruken av fengsel. Men straffnivået lå i Finland tidligere langt høyere enn i de øvrige nordiske land, og endringene der har reelt sett kun ført til at Finland er kommet på samme nivå.

Utviklingen i Norge har i de siste tiår gått i motsatt retning idet vi har fått en økning av fangetallet.

Ser man på reaksjonene ved forbrytelser har den prosentvise andelen som blir idømt ubetinget fengsel også økt betydelig dersom vi for eksempel sammenligner med tallene fra 1970.

En del av forklaringen på dette kan være at et langt større antall av forbrytelsene har blitt grovere. Det er iallfall dekning for å kunne si at den totale økningen av frihetsstraffen i Norge ikke har tilsvart kriminalitetsøkningen.

Økningen av fangetallet $i$ de siste to ti-år skyldes nok først og fremst kampen mot narkotika. Særlig på 1980-tallet fikk vi i Norge en kraftig økning av strafferammene og da slik at også domstolene fulgte lovgivers signaler og straffenivået ble betydelig hevet. I Norge gjelder omtrent halvparten av alle frihetsstraffer over 3 år narkotika og ca 1/4 av fangetallet er dømt for narkotika.

På noen områder har Norge også hatt en utvikling mot mindre bruk av fengselsstraff. Stor praktisk betydning er revisjonen i 1988 av den norske promillelovgivningen som medfører mindre bruk av fengsel på dette området.

Sverige og Finland har også hatt en oppmykning av promillelovgivningen som medfører mindre bruk av frihetsstraff.

La meg understreke at fangetallet i Norge er ikke høyere enn i de andre nordiske land - muligens noe lavere, ca 65-66 pr. 100.000. Fangetallet er for alle de nordiske land omtrent de samme: ca 65-68 regnet pr. 100.000. Dette er relativt lavt sammenlignet med mange andre land.

\section{Et nytt trusselbilde og krav om nye etterforskningsmetoder}

Med de strømninger om lov og orden som utover på 1990-tallet var fremherskende, var det grobunn for politiet til få gjennomslag for økte rammevilkår for en mer effektiv etterforskning.

I de seneste år er det vedtatt nye bestemmelser om utvidet adgang til kommunikasjonsavlytting, ransakning med utsatt underretning m.m. både i Danmark og Norge. I Sverige la et utvalg i 1988 fram nye lovforslag om avlytting og andre hemmelige tvangsmidler (SOU 1998: 46).

I disse dager vedtas i Norge flere bestemmelser for vitnebeskyttelse, og som første land i Norden en bestemmelse om adgang til anonym vitneførsel. (Lovvedtaket ble truffet på Kriminalistmøtets andre dag, den 6. juni 2000, og bestemmelsen om anonym vitneførsel ble innført i den norske straffeprosesslov som ny $\S 130 a$.) 
Behovet for nye etterforskningsmetoder er begrunnet i et nytt og alvorlig trusselbilde. I Norge viste Metodeutvalget til at kriminaliteten var blitt grovere, mer alvorlig og sofistikert, og på samme måte som i Danmark ble det argumentert med tilkomst av alvorlig organisert kriminalitet (NOU 1997:15).

Kravet om nye etterforskningsmetoder ble for øvrig først reist i Danmark og da i tilknytning til kriminaliteten blant motorsykkelbandene Hells Angels og Bandidos.

Hva angår påvist organisert internasjonal kriminalitet, er det fra politiets side - både i Danmark og Norge - uttalt at denne er begrenset. Det nevnes rett nok at store deler av innføringen av narkotika skjer organisert. Videre forekommer det en del tilfeller av menneskesmugling, biltyverier (hvor det er mest Sverige som har blitt rammet), serietyverier i distriktene av klær, kredittkortbedragerier, internasjonale investorbedragerier og hvitvasking. Samtidig understrekes at den grenseoverskridende organiserte kriminalitet er økende og stadig mer sofistikert (NOU 1997:15 og Kriminalpolitisentralens trusselvurdering 1999).

\section{Europarådet, Strasbourgdomstolen og EU}

Et markant trekk ved utviklingen av straffelovgivningen, straffeprosessen og politiets arbeidsvilkår skyldes innflytelse fra Europarådet, menneskerettighetsdomstolen i Strasbourg og EU. På flere områder står vi overfor en harmonisering av straffesystemene i Europa og en stadig styrking av politisamarbeidet.

Europarådet har i de siste to tiår gitt atskillige anbefalinger om materielle og prosessuelle bestemmelser for strafferettspleien i de enkelte land.

Og da slik at man i Europarådets regi også har iverksatt instrumenter for kontroll av at konvensjoner og tilrådinger blir implementert.

Europarådet har gitt tilrådinger av betydning for lovgivning om narkotika, styrking av offerets stilling, foretaksstraff, innføring av samfunnstjeneste som alternativ til ubetinget fengsel, hvitvasking og inndragning av formue, datakriminalitet, menneskesmugling, korrupsjon og meget annet.

I Europarådets regi har kamp mot organisert kriminalitet stått på dagsorden i hele 1990-tallet. Fra 1996 har det vært innført et system med årlig rapportering fra det enkelte land om omfang av organisert kriminalitet. I 1997 vedtok det europeiske rådet en handlingsplan for å bekjempe organisert kriminalitet. Og det tenkes nå bl.a. utviklet et system for oppfølgning og evaluering av gjennomføringen på nasjonale plan av de internasjonale tilrådinger

Det nevnes i den forbindelse at rådet også har gitt rekommendasjoner om vitnebeskyttelse $\mathrm{g}$ bruk av datateknikk under etterforskning. Videre arbeides det med en konvensjon blant annet om forbud mot og straff for medlemskap i kriminelle organisasjoner.

Nytt er også den innflytelse som Menneskerettighetsdomstolen i Strasbourg øver på straffeprossen. Jeg begrenser meg til å minne om Hauschildt og Unterpertinger. Særlig Island har endret straffeprosessordningen betydelig på grunn av Strasbourgdomstolen. 
Videre nevner jeg det omfattende politi- og tollsamarbeid som nå ses utviklet i Europa innen EU ved de to instrumenter: Schengen og SIS-systemet og Europolkonvensjonen.

Det kan i tillegg nevnes at det innen EU er utarbeidet et forslag til felles strafferettlige og straffeprosessuelle bestemmelser til vern om EUs finansielle interesser, betegnet Corpus Juris.

\section{Oppsummering}

I de siste tiår har Norge hatt en betydelig økning av nykriminaliseringer og da spesielt knyttet til forhold som gjerne blir betegnet som moderne kriminalitet (white collar crime, miljøkriminalitet og ITK-kriminalitet).

På 1990-tallet skjer en viss hevning av fengselsstraff ved voldskriminalitet og ved gjengangere av omfattende vinningskriminalitet, men frihetsstraffen har likevel vært holdt på et relativt lavt nivå sammenlignet med samme periodes økning av kriminaliteten.

Fengsel brukes i stor utstrekning mot narkotika.

Bildet er nyansert. På noen områder er det tatt i bruk mildere tiltak: I 1991 ble lovfestet konfliktråd særlig med sikte på mindre lovbrudd av unge lovovertredere, og samfunnstjeneste til erstatning for ubetinget fengsel ved vinningskriminalitet.

For å styrke rettssikkerheten til siktede er det lovfestet to instanser til prøving av skyldspørsmålet, og det er vedtatt endring i straffeprosessloven som gjør det lettere å få gjenopptatt en straffesak. For tiden arbeides det dessuten med endringer med hensyn til avgjørelsesorgan av gjenopptagelsessaker.

Lovgivningen til håndtering av farlige voldsovertredere er endret $\mathrm{i}$ retning av å snevre inn adgangen til inkapasitering. Sikringsinstituttet erstattes nå i Norge av forvaring og dom på overføring til psykisk helsevern.

Endelig - når man skal forsøke å sammenfatte hovedlinjer i kriminalpolitikken må det også vises til betydningen av det europeiske samarbeid. Mon tro det er noe i en slik spissformulering: I allfall for en ikke uvesentlig del har norsk og øvrig nordisk kriminalpolitikk vært til dels styrt av Europarådet, EU og derved også sentral-Europa. En slik påvirkning vil øke betydelig i årene fremover.

Adresse: Institutt for offentlig rett

Universitetet i Bergen

Dragefjellet

Magnus Lagabøtes Plass 1

N-5010 Bergen

E-mail: Henry.Maland@ jur.uib.no 